\title{
HOW TO USE DIGITAL LITERACY AS A LEARNING RESOURCE FOR TEACHER CANDIDATES IN INDONESIA
}

\author{
Evi Fatimatur Rusydiyah ${ }^{1 *}$, Eni Purwati ${ }^{1}$, Ardhi Prabowo ${ }^{2}$ \\ ${ }^{1}$ UIN Sunan Ampel Surabaya, Indonesia \\ ${ }^{2}$ Universitas Negeri Semarang, Indonesia \\ *e-mail: evifatimatur@uinsby.ac.id
}

\begin{abstract}
In the current era, the world of education faces challenges of how to design learning by using digital media with the intention to improve the instructional quality and students' competencies. Digital media are important in the world of education since they help teachers to present materials contextually, visually, interestingly, and interactively. The present study was aimed at identifying student teachers' perceptions on the use of digital literacy as a learning resource. The study was a survey involving students of the universities that had a partnership with USAID Priority as the research population. A total sample of 168 students were selected from seven universities. Data were collected using questionnaires, interviews, and documentation. The weighting of the questionnaire scores used the Likert's scale. The variable Digital Literacy consisted of four indicators of ICT basic competencies, informational skills, media awareness, and computational thinking. The findings showed that the student teachers had good perceptions in the use of digital literacy as a learning resource. On the ICT basic skill indicator, the average score was at the high category; on the informational skill indicator, the average score was at the very high category; on the media awareness, the average score was at the high category; and on the computational thinking indicator, the average score was at the medium category.
\end{abstract}

\section{Keywords: perception, digital revolution, digital literacy, learning resource}

\section{BAGAIMANAKAH PEMANFAATAN DIGITAL LITERASI SEBAGAI SUMBER BELAJAR BAGI CALON GURU DI INDONESIA?}

\begin{abstract}
Abstrak: Dewasa ini dunia pendidikan dihadapkan pada tantangan untuk mendesain pembelajaran dengan memanfaatkan media digital sebagai sarana untuk meningkatkan kualitas pembelajaran dan pengetahuan siswa. Media digital penting untuk diterapkan dalam dunia pendidikan karena mampu menyajikan materi pembelajaran secara konstekstual, visual, dan audio yang menarik dan interaktif. Penelitian ini bertujuan untuk mengetahui persepsi mahasiswa calon guru tentang pemanfaatan literasi digital sebagai sumber belajar. Penelitian ini menggunakan pendekataan survei. Populasi penelitian adalah mahasiswa dari perguruan tinggi yang memiliki kerja sama dengan USAID Prioritas. Sampel penelitian adalah 168 mahasiswa yang berasal dari tujuh universitas di Indonesia. Teknik pengumpulan data yang digunakan adalah angket, wawancara, dan dokumentasi. Pembobotan skor kuesioner ini menggunakan skala likert. Indikator literasi digital yang menjadi pertanyaan terdiri atas empat indikator, yaitu kemampuan dasar teknologi informasi dan komunikasi (TIK), keterampilan informasi, kesadaran media, dan pemikiran komputasi. Hasil penelitian menunjukkan bahwa mahasiswa calon guru memiliki persepsi yang baik dalam memanfaatkan literasi digital sebagai sumber belajar. Pada indikator kemampuan dasar teknologi informasi dan komunikasi berada pada kategori tinggi, indikator keterampilan informasi berada pada kategori sangat tinggi, indikator kesadaran media berada pada kategori tinggi, dan indikator pemikiran komputasi barada pada kategori cukup tinggi.
\end{abstract}

Kata Kunci: persepsi, revolusi digital, literasi digital, sumber belajar 


\section{INTRODUCTION}

Educational curricula experience changes over time. One reason for curriculum changes at present is the continuing digital revolution (Lamers \& Van Den Oetelaar, 2012). The impact of such changes also influences one's view of learning resources. This view begins from how the teacher is seen as the only learning resource. Still now, it has changed in that learning resources can come from various learning resources such as textbooks, print and electronic media, nature in the environment, and other such relevant learning resources (Permendikbud RI 2016 No. 22). This is also in accord with the on-going industrial revolution that demands all educational caretakers to be able to adapt to changes motorized by informational technology as the agent of change (Fraillon, Ainley, Schulz, Friedman, \& Gebhardt, 2013). A learning resource is that which is related to human beings, data, and things that make it possible for learners to use optimally as a facility in learning (Ely \& Gerlach, 1978). There are some criteria in the selection of useful learning resources, among others: their availability, their possibility for learners to refer to themselves, and their ability to satisfy the learners' needs for independent learning (Percival \& Ellington, 1984; Warsita, 2018).

Digital literacy-based learning resources become important to be applied in the world of education since they can present instructional materials contextually, visually, and aurally in interesting and interactive ways (Setyaningsih \& Prihantoro, 2012). As cited in the Decree of the Minister of Education Number 22 the Year 2016 about primary and secondary education process standard, information and communication technology must be applied integratively, systematically, and effectively by considering the condition and situation in the field (Permendikbud RI 2016 No. 22). This Minister's decree gives a signal that the implementation of digital literacy plays an important role in producing learning resources that are effective and efficient.

The use of digital literacy in the educational sector is not separated from the function of the class teacher. As stated in the Law of The Republic Indonesia Number 14 Year 2005 about the teachers and university lecturers, the teacher is one who is a professional educator with the main duty of educating, teaching, guiding, directing coaching, testing, and evaluating infant students through formal education programs, students of the primary education, and students of the secondary education (Undang-Undang RI 2005 No. 14). One of the competences of a professional teacher is to master the skills in operating information and communication technology. This competency must appropriately complete with functional digital literacy.

Digital literacy competencies consist of using, understanding, accessing, managing, gathering, and evaluating information from information and communication technologybased (ICT-based) sources (TIK) (Siero, 2017). Platform Onderwijs 2032 defines digital literacy as the competence to work on the computer to collect, process, and share information in secure and conscious manners (Schnabel, ten Dam, Douma, van Eijk, Tabarki, van der Touw, ... \& Visser, 2016). Fraillon et al. (2013) define digital literacy as any digital-based effort that can be used as learning sources. In this concern, the present study focuses on four indicators of digital literacy, namely: 1) basic competences of ICT, 2) information skills, 3) media awareness, and 4) computational thinking (Siero, 2017).

The study is expected to give wouldbe teacher students factual descriptions of the importance of using digital literacy as learning resources. Perceptions are individuals' processes in receiving sensory impressions to be interpreted in such that can give usefulness to give meaning to the events in the environment (Beaumont, 2012). The perception of teacher candidate students concerning the importance of using digital literacy as a learning resource is a process in the would-be teacher students to interpret and give responses in the forms of opinions, actions, acceptance, or rejection.

Several studies have been conducted on the implementation of digital literacy in the world of education such as Miskiah, Suryono, \& Sudrajat (2019); Chan, Churchill, \& Chiu (2017); Njenga (2018); Mudlofir \& Rusyidah (2016); Thohir, Kurjum, \& Muhid (2020); and Kim (2019). The present study has a difference from previous studies in that it analyzes the perceptions of candidate teacher students in using digital literacy as a learning resource. It is a fact that very few studies take account of this aspect of teacher candidates. Teacher candidates, 
who become an important component in the continuation of the education system, must be given the appropriate portion to be analyzed. They are the continuing generation of the teachers who later will retire. It is, therefore, essential to find out just what they have in mind about the application of digital literacy as an essential learning resource.

The previous fact has been supported by several cases during the running of the teachers' training for certification. In this activity, many of the class sessions use on-line instruction. It is found that many teachers do not have the knowledge and skills in operating computers for digital literacy learning. This context is in accord with what Chikasha, Sundarjee, Ntuli, \& Chikasha (2013) find in Johannesburg that not all the teachers have felt comfortable when integrating ICT as a learning source at school. In fact, Teachers' competence in using learning resources has an impact on the better achievement of the students, as has been found by Hendarwati (2013); Setiyani (2010); and Warsita (2018) in their studies. It is therefore reasonable that the perceptions of would-be teacher students on the use of digital literacy as a learning resource need to be studied. By this reasoning, the teaching university will be able to take cautious preventive measures when they find that the students have not possessed positive perceptions in the use of digital literacy as a learning resource.

The study then is aimed at finding out the perception of the teacher candidate students concerning with the use of digital literacy as a learning resource. The construct of literacy used in this study is covered by four indicators, namely: basic competences of ICT, information skills, media awareness), and computational thinking (Fraillon et al., 2013; Siero, 2017).

\section{METHODS Approach}

The study was quantitative research using the survey design. The survey was supported by several criteria that were beneficial in the study. These, among others, were the high representation of the results, low cost, ease in data collection, favorable statistical significances, low level of the researcher's subjectivity, and accurate research findings (Werang, 2015).

\section{Data Source}

The research data used in the study were primary data elicited from university students as research informants either individually or in groups (Hasan, 2002). The research population referred to students of universities who had a partnership with USAID Priority, a USAIDfunded cooperative program by the governments of the United States of America and Indonesia, designed to improve access to primary education in Indonesia. (USAID Prioritas, 2012). A sample of 168 students was selected from seven universities in Indonesia, as presented in Table 1.

Members of the research sample were selected using random techniques from various random-sampling methods that were simultaneously used in effective and efficient manners.

\section{Research Instruments}

The two instruments used in the present study were a questionnaire and a documentation. The questionnaire consisted of a set of questions subjected to the research respondents (Roopa \& Rani, 2012; Kriyantono, 2006) using the Likert scale (Joshi, Kale, Chandel, \& Pal, 2015) of 1 to 4 ranges from agree to disagree.

Table 1. Research Sample by University Origin, Number, and Percentage

\begin{tabular}{clcc}
\hline No. & \multicolumn{1}{c}{ University Origin } & Number & Percentage \\
\hline 1. & Sunan Ampel State Islamic University, Surabaya & 28 & 17 \\
2. & Alauddin State Islamic University, Makassar & 27 & 15 \\
3. & Surabaya State University & 30 & 15 \\
4. & Semarang State University & 20 & 12 \\
5. & Indonesia Education University & 21 & 15 \\
6. & Yogyakarta State University & 20 & 14 \\
7. & North Sumatera State Islamic University & 22 & 12 \\
\hline & Total & $\mathbf{1 6 8}$ & $\mathbf{1 0 0}$
\end{tabular}


Tabel 2. Results of the Computation of Aiken's Values of the Questionnaire Items

\begin{tabular}{cccccc}
\hline Item & Value $\boldsymbol{V}$ & Item & Value $\boldsymbol{V}$ & Item & Value $\boldsymbol{V}$ \\
\hline Q1 & .695 & Q9 & .708 & Q17 & .691 \\
Q2 & .775 & Q10 & .827 & Q18 & .637 \\
Q3 & .738 & Q11 & .771 & Q19 & .581 \\
Q4 & .819 & Q12 & .652 & Q20 & .529 \\
Q5 & .765 & Q13 & .761 & Q21 & .628 \\
Q6 & .625 & Q14 & .744 & Q22 & .565 \\
Q7 & .829 & Q15 & .735 & & \\
Q8 & .783 & Q16 & .681 & & \\
\hline
\end{tabular}

The study is concerned with students' perceptions on the use of digital literacy as a learning resource. The entity of digital literacy is constructed of four indicators, namely basic competencies in informational communication technology, informational skills, media awareness, and computational thinking (Siero, 2017; Fraillon et al., 2013). These four indicators are also used as basic digital literacy by the UNESCO. In the questionnaire, students' perceptions on the use of digital literacy as learning resource are elicited through 22 Likertscale items (Q1, Q2, ..., Q22).

Estimation for the instrument validity applied the Aiken's $V$ calculation using the following formula:

$$
V=\frac{\sum s}{n(c-1)}
$$

where

$$
\begin{array}{ll}
s=r- & l_{0} \\
l_{0} & : \text { the lowest score } \\
c & : \text { the highest score } \\
r & : \text { score given by the rater } \\
n & : \text { number of raters }
\end{array}
$$

A questionnaire item is stated as valid if the Aiken's coefficient value is Aiken's $V \geq .3$ (Azwar, 2014). Results of the computation of the Aiken's values can be seen in Table 2. Table 2 shows that the questionnaire is a valid research instrument since all the Aiken's values are higher than .60 (Nurgiyantoro, 2017).

For the reliability estimate of the questionnaire, a Cronbach's Alpha statistic has been done on the SPSS 20.0 software. The higher the Cronbach's Alpha. The higher the reliability estimate. The results of the computation show a Cronbach's Alpha score of .950, indicating that the questionnaire has a very high-reliability estimate that is very high.

\section{Data Collection Technique}

Data for the research study were collected by distributing the questionnaire in the Google Form format. The respondents were all the members in the selected sample, teachercandidate students who were included in the USAID Priority community.

\section{Data Analysis Technique}

The study used descriptive analyses in the survey approach to describe the distribution of the research data through the media of tables and graphics. Data were presented in the score categories of very high, high, medium, low, and very low. Results of the measurements of the students' perceptions were interpreted in percentages in line with Table 3 (Riduan \& Akdon, 2006).

Tabel 3. Interpretation of Questionnaire Data

\begin{tabular}{lcc}
\hline No. & Interval & Criteria \\
\hline 1. & $0 \%-20 \%$ & Very low \\
2. & $21 \%-40 \%$ & Low \\
3. & $41 \%-60 \%$ & Medium \\
4. & $61 \%-80 \%$ & High \\
5, & $81 \%-100 \%$ & Very high \\
\hline
\end{tabular}

\section{FINDINGS AND DISCUSSION \\ Findings \\ ICT Basic Competencies}

Basic competencies in information and communication technology become the first indicator of digital literacy. The competencies refer to one's abilities in using ICT for daily duties and assignments such as sending $e$-mails, video calling, browsing in the Internet, and using a tablet or cellular phone. 
It can be seen from the Table 4, on average, students' competencies in using digital literacy as a learning resource can be categorized as high. The highest average is on Scale 4 (Agree), amounting to $73.5 \%$.

\section{Informational Competencies}

Informational literacy is the second category. It is related to students' abilities in finding information, selecting relevant information, and judging the use and reliability of the information. Table 5 shows that the average of students' perceptions of using digital literacy as a learning resource is very high. It can be seen from the highest average on the Likert's scale is 4 (Agree), which is $83.4 \%$.

\section{Media Awareness}

Media awareness is the third indicator of digital literacy. In this relation, media awareness is meant the ability to access, analyze, evaluate, and communicate information in all kinds of forms. Media awareness is a set of perspectives actively used when accessing mass media to interpret the obtained data. Media awareness is also related to the understanding of responsibility. It is using social media in terms of its impacts on society at large.

From the Table 6, it can be seen that students' averages in their perceptions of the use of digital literacy as a learning resource are high. The highest Linkert's scale indicated on item 4 (Agree), which is $70 \%$.

Table 4. Categorization of Students' Perceptions in Using Digital Literacy as Learning Resource within ICT Basic Competencies

\begin{tabular}{|c|c|c|c|c|c|}
\hline \multirow{2}{*}{ No. } & \multirow{2}{*}{ Indicator } & \multicolumn{4}{|c|}{ Frequency } \\
\hline & & 4 & 3 & 2 & 1 \\
\hline 1. & $\begin{array}{l}\text { I can collect data systematically (e.g., through articles, } \\
\text { experimentation, interview, survey, or library study). }\end{array}$ & 110 & 49 & 7 & 2 \\
\hline 2. & $\begin{array}{l}\text { I can formulate problems in such a way to be able to } \\
\text { solve by using a computer or other digital devices. }\end{array}$ & 142 & 24 & 2 & 0 \\
\hline 3. & $\begin{array}{l}\text { I can analyze data (applying patterns or using statistical } \\
\text { methods). }\end{array}$ & 124 & 37 & 7 & 0 \\
\hline 4. & $\begin{array}{l}\text { I can write a computer program in codes (e.g., using } \\
\text { logos, scribbles, or programming in Excel). }\end{array}$ & 152 & 12 & 2 & 2 \\
\hline 5. & $\begin{array}{l}\text { I can visualize data digitally (e.g., in a model or } \\
\text { graphic). }\end{array}$ & 133 & 32 & 3 & 0 \\
\hline \multirow[t]{2}{*}{6.} & I can tell how to analyze data by computer. & 80 & 79 & 7 & 2 \\
\hline & Average & $\begin{array}{c}123.5 \\
(73.5 \%)\end{array}$ & $\begin{array}{c}38.8 \\
(23.1 \%)\end{array}$ & $\begin{array}{c}4.7 \\
(2.8 \%)\end{array}$ & $\begin{array}{c}1 \\
(.6 \%)\end{array}$ \\
\hline
\end{tabular}

Table 5. Categorization of Students' Perceptions in Using Digital Literacy as Learning Resource as Seen from Informational Competency Indicator

\begin{tabular}{|c|c|c|c|c|c|}
\hline \multirow{2}{*}{ No. } & \multirow{2}{*}{ Indicator } & \multicolumn{4}{|c|}{ Frequency } \\
\hline & & 4 & 3 & 2 & 1 \\
\hline 1. & I can write down a research question. & 154 & 12 & 0 & 2 \\
\hline 2. & $\begin{array}{l}\text { I can find relevant information from the Internet } \\
\text { using several ways. }\end{array}$ & 141 & 25 & 2 & 0 \\
\hline 3. & $\begin{array}{l}\text { I can select sources on the Internet on relevant and } \\
\text { substantial criteria. }\end{array}$ & 118 & 40 & 10 & 0 \\
\hline 4. & $\begin{array}{l}\text { I can process information from on-line news items, } \\
\text { reports, Web sites, blogs, and social media. }\end{array}$ & 152 & 15 & 0 & 2 \\
\hline 5. & $\begin{array}{l}\text { I can tell you how to obtain information effectively } \\
\text { and responsibly. }\end{array}$ & 136 & 29 & 3 & 0 \\
\hline & Average & $\begin{array}{c}140.1 \\
(83.4 \%)\end{array}$ & $\begin{array}{c}24.1 \\
(14.3 \%)\end{array}$ & $\begin{array}{c}3 \\
(1.8 \%)\end{array}$ & $\begin{array}{c}.8 \\
(.5 \%)\end{array}$ \\
\hline
\end{tabular}




\section{Computational Thinking}

Computational thinking is the fourth indicator. This indicator refers to the abilities to formulate problems that subsequently are resolved by way of analyses using the computer. For example, students may think of a series of data by using computer programs, or recognize patterns in the data and try to conclude, or make a concept map on the Excel programs.

The Table 7 shows that the average of students' perceptions of using digital literacy as a learning resource is quite high. The highest Linkert's scale shown on item 4 (Agree), which is $48.6 \%$.

\section{Discussion \\ ICT Basic Competencies}

Seen from the indicator of basic competencies in information and communication technology, most of the teacher-candidate students have a high perception of the importance of digital literacy as a learning resource (73.5 $\%)$. This figure indicates that students have high competencies in the use of basic ICT. This finding is in accord with studies of the same kind in other countries; for example in Turkey (Çetin, 2016; Özdemir, 2017); Nigeria (Nwosu, John, Izang, \& Akorede, 2018); Japan (Yamashita, Giang, \& Oyama, 2019); and Spain (GómezTrigueros, Ruiz-bañuls, \& Ortega-Sanchez, 2019).

Table 6. Categorization of Teacher-candidate Students' Perceptions in Using Digital Literacy as Learning Resource as Seen from Informational Media Awareness Indicator

\begin{tabular}{|c|c|c|c|c|c|}
\hline \multirow{2}{*}{ No. } & \multirow{2}{*}{ Indicator } & \multicolumn{4}{|c|}{ Frequency } \\
\hline & & 4 & 3 & 2 & 1 \\
\hline 1. & I am aware of the impacts of media on me and society. & 97 & 59 & 10 & 2 \\
\hline 2. & $\begin{array}{l}\text { I can use (social) media to make, present, and share } \\
\text { various pieces of information. }\end{array}$ & 134 & 30 & 2 & 2 \\
\hline 3. & $\begin{array}{l}\text { I can participate constructively in social media such as a } \\
\text { weblog, twitter, and Facebook and other social media. }\end{array}$ & 130 & 33 & 3 & 2 \\
\hline 4. & I can use media consciously and responsibly. & 123 & 42 & 3 & 0 \\
\hline 5. & I can tell you how to use the media wisely. & 104 & 55 & 7 & 2 \\
\hline & Average & $\begin{array}{l}117.6 \\
(70 \%)\end{array}$ & $\begin{array}{c}43.8 \\
(26 \%)\end{array}$ & $\begin{array}{c}5 \\
(3 \%)\end{array}$ & $\begin{array}{c}1.6 \\
(1 \%)\end{array}$ \\
\hline
\end{tabular}

Table 7. Categorization of Teacher-candidate Students' Perceptions in Using Digital Literacy as Learning Resource as Seen from Computational Thinking Indicator

\begin{tabular}{|c|c|c|c|c|c|}
\hline \multirow{2}{*}{ No. } & \multirow{2}{*}{ Indicator } & \multicolumn{4}{|c|}{ Frequency } \\
\hline & & 4 & 3 & 2 & 1 \\
\hline 1. & $\begin{array}{l}\text { I can collect data systematically (e.g., through } \\
\text { articles, experimentation, interview, survey, or library } \\
\text { study). }\end{array}$ & 103 & 60 & 5 & 0 \\
\hline 2. & $\begin{array}{l}\text { I can formulate problems such that they can be } \\
\text { resolved by computer or other digital devices. }\end{array}$ & 91 & 64 & 13 & 0 \\
\hline 3. & $\begin{array}{l}\text { I can analyze data (find patterns or us statistical } \\
\text { methods). }\end{array}$ & 71 & 72 & 22 & 3 \\
\hline 4. & $\begin{array}{l}\text { I can write a computer program in codes (e.g., using } \\
\text { logos, scribbles, or programming in Excel). }\end{array}$ & 59 & 67 & 34 & 8 \\
\hline 5. & $\begin{array}{l}\text { I can visualize data digitally (e.g., in a model or } \\
\text { graphic). }\end{array}$ & 84 & 68 & 13 & 3 \\
\hline \multirow[t]{2}{*}{6.} & I can tell how to analyze data by computer. & 62 & 79 & 24 & 3 \\
\hline & Average & $\begin{array}{c}78.3 \\
(48.6 \%)\end{array}$ & $\begin{array}{c}68.3 \\
(39.4 \%)\end{array}$ & $\begin{array}{c}18.6 \\
(10.3 \%)\end{array}$ & $\begin{array}{c}2.8 \\
(1.7 \%)\end{array}$ \\
\hline
\end{tabular}


This study uses indicators developed by Umar \& Yusoff, 2014; Umar \& Jalil, 2012, and the T-PACT model and UNESCO (UNESCO, 2008). The basic competencies in ICT refer to those abilities to understand the work of the computer and its nets to solve the problems of the limitations of various technological devices. These basic competencies are, among others too, 1) operate, connect, install, and delete programs; 2) use office applications (such as Ms. Word, PowerPoint, Excel, and others) efficiently and effectively; 3) share information in operating the computer generally; 4) operate Internet applications such as browsing, the $E$-mail, and others effectively and efficiently; 5) have awareness in the privacy and security aspects in the use of the Internet; and 6) tell others how to use basic ICT competencies effectively.

Studies in other countries have used indicators that are similar or different. This is caused by the fact that those studies see the abilities of the teacher-candidate students in using ICT basic competencies from different variables. In the Turkish study by Cetin (2016), for example, they see the use of ICT basic competencies in Computer-Aided Education (CAE), Hypermedia, Distance learning, and databased management. The teacher candidates are seen to have acquired the necessary knowledge from literature that develops at the present time. They are also found to have had the skills to operate the computer as a part of their teaching activities. In cases in the same country, Özdemir (2017) finds that the abilities of teachers in Turkey in the use of basic ICT can be categorized as very good. These teachers' abilities are seen from the variables of gender, teaching experience, and level of education. Across these variables, there is a strong relationship between the teachers' attitudes and skills in the use of ICT in their instructional processes.

In the case of Japan, Yamashita et al. (2019) find that, with the fast development in technology, the Japanese Government has the policy of funding competitive research studies. That is in accordance with the basic design of the development of science and technology in Japan by adopting mathematic modeling techniques. The survey is conducted on 61 Japanese campuses, including those of the educational fields. They find that teacher-candidate students in Japan acquire the attitudes of competitiveness in improving their competencies in the use of ICT as capital in developing their teaching creativities. These findings, on the other hand, are in contrast with those of Gómez-Trigueros et al. (2019) in which there is a lack of understanding in the basic technological concepts that have an impact on the students' creativities in planning their lessons that are technologically integrated. Gomes et. al., however, show that the teachers' inabilities to comprehend the ICT concepts become an important factor in their skills in creatively developing technologybased instruction. They suggest that attempts are needed to support these teacher students to have basic ICT skills.

The foregoing discussion on these studies has supported the findings of the present study in that basic skills in ICT are important for the teacher-candidate students in relation to the development of their digital literacy skills. It is true that innovative teachers need to have skills in conducting adaptation to technological development (Zubaidah, 2017).

\section{Informational Competencies}

Based on the results of the data analyses on students' perceptions concerning the use of digital literacy as a learning resource, the majority of the students score very high (83.4\%). This figure is seen as a very high score.

The study uses indicators developed by Shao \& Pupur (2016) and Mccartin, Evers \& Maekowski (2019). Informational competencies refer to one's abilities in formulating and analyzing information by way of critical and systematic approaches. These indicators include skills to 1) develop research questions; 2) find relevant information in the Internet using various methods; 3 ) select sources on the internet-based on relevant and substantial criteria; 4) process information through on-line news items, reports, Web sites, blogs, and social media; and 5) tell others how to obtain information effectively and responsibly.

Similar studies on informational skills in different contexts come from Townsend, Hofer, Hanick, \& Brunetti (2016); Pieterse, Greenberg, \& Santo(2018), Klucevsek(2017); Tewell(2015); Hinchliffe, Rand, \& Collier (2018); and Holliday (2017). The results of the results have similar to acquire information skills. While the current study uses teacher candidates as informants, 
that of Townsend et al. (2016) use expert practitioners and senior teachers. The research question reads whether the threshold concepts are able to improve students' achievements. The first research question deals with whether or not the threshold-concept approach is useful for informational literacy learning. Research findings show a unanimous opinion that the threshold-concept approach plays an important role in the development of informational literacy learning. The second research question deals with what threshold concepts are needed for informational literacy learning. The research panel comes with 50 potential threshold concepts but ends up proposing six; namely authority, format, information commodities, information structures, research process, and scholarly discourse.

In the study by Pieterse et al. (2018), the informants are students of the first year studying Hebrew and Arabic. It is found that students have a good level of information. The difference lies in the fact that the Hebrew students need Arabic to understand the information. However, none of the language students are found to have speed and accuracy in accessing information. Meanwhile, in Klucevsek (2017), it is found that students need informational skills in science learning to improve their learning achievement.

In the study by Hinchliffe et al. (2018), it is found that, in their fifth year, students experience misunderstanding in informational literacy and try to develop a framework for informational literacy misunderstanding. The misunderstanding occurs in relation to the use of the library, access to information, and research processes. The study tries to respond to anxieties among researchers on the trend of studies that put more emphasis on the product rather than the process of information literacy as an important part of learning achievement. It is supported by Tewell (2015), who suggests that failure in informational literacy is partly caused by the librarian factor in that librarians have not done enough in providing complex information; in offering literature the most critical way. This belongs to critical pedagogical skills that must be owned by librarians. Holiday (2017) strengthens this matter by stating that students need advocation by librarians as part of their duties as library workers.

\section{Media Awareness}

Data are analyzed on the teacher-candidate students on the importance of digital literacy as a learning resource seen from the media awareness indicator. Results show that the perceptions of the majority of the students concerning the use of digital literacy in reference to media awareness can be categorized as high. This is shown by a percentage value of $70 \%$, which is a high score.

Indicators for media awareness have been developed from Tagg \& Seargeant (2019). Media awareness is defined to include the knowledge, skills, and attitudes of students in their feats to behave consciously, actively, and critically in the media world. This can be seen from the use of social media in the interactions of the members of the community in their daily life activities, including facilitation for students with learning resources and media. The indicators are 1) awareness of the impacts media have on the self and the members of the community; 2) awareness of social media use to make, present, and share various pieces of information; 3) constructive participation in social media such as the Weblog, Twitter, Facebook, and others; 4) conscious and responsible use of media; and 5) ability to tell others about using media wisely.

Research on media awareness of digital literacy can be found in Fitryarini (2014); Bulger \& Davison (2018); Akcayoglu \& Daggol (2019); Solmaz (2017); and Bergstrom, Flynn, \& Craig (2018). These studies have seen media awareness from a number of sides. The biggest challenge of media literacy is the massiveness of the impacts of digital-based information on all fronts of human life; not only politically and economically, but also educationally (Bulger \& Davison, 2018). Seen from the communication science, Fitryarini (2014) finds that the media literacy of younger students at the Communication Science Study Program is at the beginner level. On this level, students have acquired the introduction to media use and its potential positive and negative effects.

The study by Akcayoglu \& Daggol (2019) is intended to help students with critical competence and literacy in the form of media to be able to interpret what they see and hear and to avoid misinterpretation of information. This study has a close similarity with the present study in terms of the fact that students' perceptions on media literacy need to be taken into consideration. In almost the same way, the 
two studies believe that, if teacher candidates have positive perceptions on the use and awareness of media literacy, they will be able to facilitate their future students with guidance and direction to obtain good information.

These foregoing studies show that there is a threat on media awareness if teachers are not able to secure media awareness in learning. Bergstrom et al. (2018), on the other hand, see the positive side: in the control and experiment group design, the experiment group receiving the intervention of media literacy show awareness in the use of media literacy.

The present study can therefore be regarded as a preventive measure. Along with the advancement of the use of social media used by students in the interaction with their environment, it is important to look at the perceptions of the teacher-candidate students on the use of digital literacy as a learning resource seen from the aspect of media awareness. The results are the same as those of the first indicator (ICT Basic Competencies) and second indicator (Informational Competencies) on the high levels. This can be taken as an indication that the teacher-candidate students have good media awareness. It is therefore important that efforts in developing media awareness integrated in the learning process need to be conducted.

\section{Computational Thinking}

In the indicator or computational thinking, results of the data analyses on the teacher-candidate students' perceptions on the importance of digital literacy as a learning resource show an average score of $48.6 \%$. This is a medium score showing that many students have favourable perceptions on the importance of digital literacy in relation to the indicator of computational thinking.

Development of the indicators of computational thinking is based on the research instrument by Città, Gentile, Allegra, Arrigo, Conti, \& Ottaviano (2019); and Angeli \& Giannakos (2019). Computational thinking is an aspect that is related to problem-solving using a lot of information and computation. Students need to be able to think gradually, understand logarithm, and apply it to a computer program. They need to get in touch with the development of information to be used maximally on the computer (Angeli \& Giannakos, 2019; Città et al., 2019). The indicators to be developed include 1) the ability to collect data systematically (such as from surveys, interviews, experiments, and library studies; 2) the ability to formulate problems such that it makes it possible the solution by computer or other digital devices by coding and calculating data; 3 ) the ability to analyze data (find patterns or statistical methods); 4) the ability to write a computer program in codes (such as by using logos, scribbles, or Excel programming); 5) the ability to make digital visualization (such as by models or graphics); and 6) the ability to tell others how to analyze data by using the computer.

Much research has been done on the subject of computational thinking. Juškevičienè (2020) finds that computational thinking can be integrated into all classroom activities and all subject lessons. It is important for the class teacher to do an analysis on how to help students with computational thinking. In another study, Williams, Matt, \& O'Reilly (2014) find that one of the students' satisfying experiences is when the class teacher comes in with an instructional design that makes use of digital literacy as one of the learning resources.

Computational thinking is not limited to mathematics learning (Lockwood, Asay, DeJarnette, \& Thomas, 2016; Promraksa, Sangaroon, \& Inprasitha, 2014; Puspitasari, In'am, \& Syaifuddin, 2019). Computational thinking is also found in music learning (Bell \& Bell, 2018) and language learning (Li \& Lee, 2016). These research studies show that all teachers need to have computational skills in running their classes.

The professional teacher development programs (such as the T-PACT model) suggest that teachers' competencies in facilitating learning for students are not merely concerned with content mastery and pedagogical skills. They also include teachers' competencies in computational thinking (CCSSOs, 2011; UNESCO, 2008).

The results of the present study offer support to other similar studies despite the fact that the students' scores in computational skills are categorized as just enough. It is highly suggested that further research be done by integrating the curriculum in a way that computational skills are included in the subject matters. With these efforts, it is expected that 
the computational skills of the teacher-candidate students can improve.

The results of the present study are in agreement with those of other studies concerning the importance of the use of digital literacy as a learning resource. In the study by (Scanlon, Jones, Barnard, Thompson, \& Calder, 2000), they describe an assessment approach to evaluate the instructional technology they have developed for the last 25 years. In one of their findings, they state that the use of digital literacy as a learning resource is more effective and make it easier for students to improve their learning quality. In general, they suggest that the use of ICT in education be developed further since it has a significant impact on the improvement of students' achievement.

Finally, another study is conducted by Ming-Hung Lin and team on the impact of digital learning on the students' learning motivation and achievement (Lin, Chen, \& Liu, 2017). They find that digital learning carries a positive effect on students' motivation and achievement than traditional learning. The researchers propose that digital learning methods be optimized in the present trends of instruction by making use of the strengths of digital learning to develop practical and effective learning strategies.

\section{CONCLUSION}

The development in the digital revolution has necessitated teachers, and teachers-would be to be able to adapt themselves to providing students with digital learning resources. It is therefore reasonable that attention must be given on the teacher's and candidates' professional competencies in using digital literacy in their instructional commitments. This matter becomes more obvious, seeing that teacher candidates will sooner or later become school teachers in the digital era. Moreover, the use of digital literacy in classroom learning is an inevitable venture. Teachers' digital competencies become an important part of their teaching abilities in accordance with the challenges arising from their students' conditions in the field.

The study has shown the tendency that Indonesian teacher students' competencies in the use of digital literacy as a learning resource can be categorized as good. The first three indicators of ICT basic competencies, informational skills, and media awareness, have been identified as having a good score. Meanwhile, the fourth, computational thinking, is still on the level of enough. These research findings show that students' skills in data management still need to be improved. There is an urgent need for universities to scaffold their curricula with digital literacy. University lecturers must help students with instructional habituation so that their digital competencies stay constant or, even, improve until they leave their study program. They are expected to be graduates who will always update themselves to the development and implementation of digital literacy as a learning resource. They will need to exercise their ICT basic competencies, informational skills, and media awareness and improve their computational thinking capacities. This applies not only to mathematics fields but also to all the other subject lessons. Subsequently, this will help students in managing data visually and interestingly through graphics and other digital formats.

\section{REFERENCES}

Akcayoglu, D. I., \& Daggol, G. D. (2019). A study on the perceived media literacy level of preparatory year students in a university setting. Contemporary Educational Technology, 10(4), 416-429. doi:10.30935/cet.634195.

Angeli, C., \& Giannakos, M. (2019). Computational thinking education: Issues and challenges. Computational Thinking Education: Issues and Challenges, 105(4), 2-8. doi:10.1016/j.chb.2019.106185.

Azwar, S. (2014). Reliabilitas dan validitas. [Reliability and validity]. Yogyakarta: Pustaka Pelajar.

Beaumont, R.(2012). An introduction to principal component analysis \& factor analysis using SPSS 19 and $R$ (psych package). http://assessment-matters.weebly.com/ blogs/an-introduction-toprincipalcomponent-analysis-factor-analysisusingspss-19-and-r-psych-package.

Bell, J., \& Bell, T. (2018). Integrating computational thinking with a music education context. Informatics in Education, 17(2), 151-166. doi:10.15388/ 
infedu.2018.09.

Bergstrom, A. M., Flynn, M., \& Craig, C. (2018). Deconstructing media in the college classroom: A longitudinal critical media literacy intervention. Journal of Media Literacy Education, 10(3), 113131. doi:10.23860/JMLE-2018-10-03-07.

Bulger, M., \& Davison, P. (2018). The promises, challenges, and futures of media literacy. Journal of Media Literacy Education, 10(1), 12-13. doi:10.23860/JMLE-201810-1-1.

CCSSO (Council of Chief State School Officers). (2011, April). Interstate Teacher Assessment and Support Consortium (InTASC) model core teaching standards: A resource for state dialogue. Washington, DC: Author.

Çetin, O. (2016). The views of science preservice teachers about the usage of basic information technologies (bit) in education and instruction. Journal of Education and Training Studies, 4(9), 120-129. doi:10.11114/jets.v4i9.1652.

Chan, B. S. K., Churchill, D., \& Chiu, T. K. F. (2017). Digital literacy learning in higher education through digital storytelling approach. Journal of International Education Research (JIER), 13(1), 1-16. doi:10.19030/jier.v13i1.9907.

Chikasha, S., Sundarjee, R., Ntuli, M., \& Chikasha, J. (2013). ICT integration in teaching: An uncomfortable zone for teachers: A case of schools in Johannesburg. Education as Change, 18(1), 137-150. doi:10.1080/16823206.2 013.847013 .

Città, G., Gentile, M., Allegra, M., Arrigo, M., Conti, D., \& Ottaviano, S. (2019). The effects of mental rotation on computational thinking. Computers \& Education, 141(4), 2-10. doi:10.1016/j. compedu.2019.103613.

Ely, D. P., \& Gerlach. (1978). Book of reading in instructional technology center for instructional development. New York,
NY: Cyracuse Unvirsity.

Fitryarini, I. (2014). Literasi media pada mahasiswa Prodi Ilmu Komunikasi Universitas Mulawarman. [Media literacy at students of the Communication Studies Program at Mulawarman University]. Jurnal Komunikasi, 8(1), 51-67. doi:10.24912/jk.v8i1.46.

Fraillon, J., Ainley, J., Schulz, W., Friedman, T., \& Gebhardt, E. (2013). Preparing for life in a digital age the IEA international computer and information literacy study international report. Melbourne: Australian Council for Educational Research (ACER).

Gómez-Trigueros, I. M., Ruiz-Bañuls, M., \& Ortega-Sanchez,D. (2019). Digital literacy of teachers in training: Moving from ICTS (information and communication technologies) to LKTs (learning and knowledge technologies). Education Sciences, 9(274), 1-10. doi:10.3390/ educsci9040274.

Hasan, M. I. (2002). Pokok-pokok materi metodologi penelitian dan aplikasinya. [The main methodology research material and its application]. Bogor: Ghalia Indonesia.

Hendarwati, E. (2013). Pengaruh pemanfaatan lingkungan sebagai sumber belajar melalui metode inkuiri terhadap hasil belajar siswa SDN I Sribit Delanggu pada pelajaran IPS. [The influence of the environment as a learning resource utilization through inquiry method on student learning outcomes SDN I Sribit Delanggu in social studies] Pendagogia, 2(1), 59-70. doi:10.21070/pedagogia. v2i1.47.

Hinchliffe, L. J., Rand, A., \& Collier, J. (2018). Predictable information literacy misconceptions of first-year college students. Communications in Information Literacy, 12(1), 4-18. doi:10.15760/ comminfolit.2018.12.1.2.

Holliday, W. (2017). Frame works: Using metaphor in theory and practice in 
information literacy. Communications in Information Literacy, 11(1), 4-20. doi:10.15760/comminfolit.2017.11.1.44.

Joshi, A., Kale, S., Chandel, S., \& Pal, D. (2015). Likert scale: Explored and explained. British Journal of Applied Science \& Technology, 7(4), 396-403. doi:10.9734/ bjast/2015/14975.

Juškevičienè, A. (2020). STEAM teacher for a day: A case study of teachers' perspectives on computational thinking. Informatic in Education, 19(1), 33-50. doi:10.15388/ infedu.2020.03.

Kim, K. T. (2019). The structural relationship among digital literacy, learning strategies, and core competencies among South Korean college students. Educational Sciences: Theory and Practice, 19(2), 3-21. doi:10.12738/estp.2019.2.001.

Klucevsek, K. (2017). The intersection of information and science literacy. Communications in Information Literacy, 11(2), 354-365. doi:10.15760/ comminfolit.2017.11.2.7.

Kriyantono, R. (2006). Teknik praktis riset komunikasi. [Practical techniques of communication research]. Jakarta: Kencana Prenada Media Group.

Lamers, H., \& Van Den Oetelaar, F. (2012). 21st century skills in het Onderwijs. http:// www.21stcenturyskills.nl/whitepaper.

Li, L.-Y., \& Lee, L.-Y. (2016). Computer literacy and online learning attitude toward GSOE students in distance education programs. Higher Education Studies, 6(3), 147-156. doi:10.5539/hes.v6n3p147.

Lin, M. H., Chen, H. C., \& Liu, K. S. (2017). A study of the effects of digital learning on learning motivation and learning outcome. Eurasia Journal of Mathematics, Science and Technology Education, 13(7), 35533564. doi:10.12973/eurasia.2017.00744a.

Lockwood, E., Asay, A., DeJarnette, A. F., \& Thomas, M. (2016). Algorithmic thinking: An initial characterization of computational thinking in mathematics. In M. B. Wood, E. E. Turner, M. Civil, \& J. A. Eli (Eds.). (2016). Proceedings of the $38^{\text {th }}$ annual meeting of the North American chapter of the international group for the psychology of mathematics education. Tucson, AZ: The University of Arizona, pp. 1588-1595.

Mccartin, L. F., Evers, S., \& Markowski, B. (2019). Student perceptions of information literacy skills and curriculum before and after completing a research assignment. The Journal of Academic Librarianship, 45(3), 262-267. doi:10.1016/j. acalib.2019.03.009.

Miskiah, M., Suryono, Y., \& Sudrajat, A. (2019). Integration of information and communication technology. Cakrawala Pendidikan,38(1), 130-140. doi:10.21831/ cp.v38i1.23439.

Mudlofir, A., \& Rusyidah, E. F. (2016). Desain pembelajaran inovatif. [Innovative learning design]. Jakarta: Raja Grafindo Persada.

Njenga, J. (2018). Digital literacy: The quest of an inclusive definition. Journal of the Reading Association of South Africa, 9(1), 1-7. doi:10.4102/rw.v9i1.183.

Nurgiyantoro, B. (2017). Penilaian pembelajaran bahasa berbasis kompetensi. [Competency-based language learning assessment]. Yogyakarta: BPFE.

Nwosu, John, Izang, \& Akorede. (2018). Assessment of information and communication technology (ICT) competence and literacy skills among undergraduates as a determinant factor of academic achievement. Educational Research and Reviews, 13(15), 582-589. doi: 10.5897/ERR2018.3539.

Özdemir, S. (2017). Basic technology competencies, attitude towards computer assisted education and usage of technologies in Turkish lesson: A correlation. International Education Studies, 10(4), 160-171. doi:10.5539/ies. v10n4p160. 
Percival, F., \& Ellington, H. (1984). Teknologi pendidikan. [Education technology]. Jakarta: Erlangga.

Permendikbud RI 2016 No. 22. Standar Proses Pendidikan Dasar dan Menengah. [Primary and Secondary Education Process Standard].

Pieterse, E., Greenberg, R., \& Santo, Z. (2018). A multicultural approach to digital information literacy skills evaluation in an Israeli college. Communications in Information Literacy, 12(2), 107-127. doi:10.15760/comminfolit.2018.12.2.4.

Promraksa, S., Sangaroon, K., \& Inprasitha, M. (2014). Characteristics of computational thinking about the estimation of the students in mathematics classroom applying lesson study and open approach. Journal of Education and Learning, 3(3), 56-66. doi:10.5539/jel.v3n3p56.

Puspitasari, L., In'am, A., \& Syaifuddin, M. (2019). Analysis of students' creative thinking in solving arithmetic problems. International Electronic Journal of Mathematics Education, 14(1), 49-60. doi:10.12973/iejme/3962.

Riduan, R., \& Akdon, A. (2006). Rumus dan data dalam aplikasi statistika untuk penelitian. [Rumus dan data dalam aplikasi statistika untuk penelitian]. Bandung: Alfabeta.

Roopa, S., \& Rani, M. (2012). Questionnaire designing for a survey. The Journal of Indian Orthodontic Society, 46(4), 273277. doi:10.5005/jp-journals-10021-1104.

Scanlon, E., Jones, A., Barnard, J., Thompson, J., \& Calder, J. (2000). Evaluating information and communication technologies for learning. Educational Technology and Society, 3(4), 101-107. doi:10.1016/j.sbspro.2009.01.375.

Schnabel, P., ten Dam, G., Douma, T., van Eijk, R., Tabarki, F., van der Touw, A., ... \& Visser, M. (2016). Ons onderwijs 2032: Eindadvies. [Our education 2032: Final advice]. Den Haag: Platform Onderwijs 2032.
Setiyani, R. (2010). Pemanfaatan internet sebagai sumber belajar. [Utilization of the internet as a source of learning]. Jurnal Pendidikan Ekonomi Dinamika Pendidikan, 5(2), 117-133. doi:10.15294/ dp.v5i2.4921.

Setyaningsih, R., \& Prihantoro, E. (2012). Model penguatan literasi digital melalui pemanfaatan e-learning. [Model of strengthening digital literacy through the use of e-learning]. Jurnal Aspikom, 3(6), 1200-1214. doi:10.24329/aspikom. v3i6.333.

Shao, X., \& Purpur, G. (2016). Effects of information literacy skills on student writing and course performance. The Journal of Academic Librarianship, 42(6), 670-678. doi:10.1016/j. acalib.2016.08.006.

Siero, N. B. (2017). Guidelines for supporting teachers in teaching digital literacy. Netherlands: University Of Twente.

Solmaz, O. (2017). Adapting new media literacies to participatory spaces: Social media literacy practices of multilingual students. Journal of Media Literacy Education, 9(1), 36-63. doi:10.23860/ JMLE-2017-9-1-4.

Tagg, C., \& Seargeant, P. (2019). Context design and critical language/media awareness: Implications for a social digital literacies education. Linguistics and Education, 1-9. doi:10.1016/j.linged.2019.100776.

Tewel, E. (2015). A decade of critical information literacy: A review of the literature. Communications in Information Literacy, 9(1), 1-7. doi:10.15760/ comminfolit.2015.9.1.174.

Thohir, M., Kurjum, M., \& Muhid, A. (2020). Design and discourse of modern standard Arabic e-textbook. Litera, 19(1), 1-20. doi : 10.21831/ltr.v19i1.28901.

Townsend, L., Hofer, A. R., Hanick, S. L., \& Brunetti, K. (2016). Identifying threshold concepts for information literacy. Communications in Information Literacy, 
10(1), 23-49.doi:10.7548/cil.v10i1.344.

Umar, I. N., \& Jalil, N. A. (2012). ICT skills, practices and barriers of its use among secondary school students. Procedia - Social and Behavioral Sciences, 46(2012), 5672-5676. doi:10.1016/j. sbspro.2012.06.494.

Umar, I. N., \& Yusoff, M. T. M. (2014). A study on Malaysian teachers' level of ICT skills and practices, and its impact on teaching and learning. Procedia - Social and Behavioral Sciences, 116(February), 979984.doi:10.1016/j.sbspro.2014.01.331.

Undang-Undang RI 2005 No. 14. Guru dan dosen. [Teacher and lecturer].

UNESCO (The United Nations Educational, Scientific and Cultural Organization). (2008). ICT competency standards for teachers. France: United Nations Educational, Scientific and Cultural Organization.

USAID Prioritas. (2012, October). Selamat datang di USAID Prioritas. [Welcome to USAID Prioritas]. https://www. prioritaspendidikan.org/id/pages/view/ home.
Warsita, B. (2018). Teori belajar Robert M. Gagne dan implikasinya pada pentingnya pusat sumber belajar. [Robert M. Gagne's learning theory and its implications for the importance of learning resource centers]. Jurnal Teknodik, 12(1), 64-78. doi:10.32550/teknodik.v12i1.421.

Werang, B. R. (2015). Pendekatan kuantitatif dalam penelitian sosial. [Quantitative approach in social research]. Yogyakarta: Calpulis.

Williams, C. J., Matt, J. J., \& O'Reilly, F. L. (2014). Generational perspective of higher education online student learning styles. Journal of Education and Learning, 3(2), 33-51. doi:10.5539/jel.v3n2p33.

Yamashita, Y., Giang, H. N., \& Oyama, T. (2019). Assessing the performance of Japanese major universities through the research funding system. International Journal of Higher Education, 8(1), 1-18. doi:10.5430/ijhe.v8n1p1.

Zubaidah, S. (2017, 10 December). Keterampilan abad ke-21: Keterampilan yang diajarkan melalui pembelajaran. [21st Century Skills: Skills taught through learning]. Paper presented in Seminar Nasional Pendidikan, STKIP Persada Khatulistiwa, Sintang, Kalimantan Barat. 